\title{
The Role of Services in Total Productivity Growth of Indian Manufacturing Firms: A Firm Level Analysis Since 2000
}

\author{
Sonia Mukherjee ${ }^{1}$ \\ 'Consultant, Ministry of Finance, New Delhi, India \\ Email:sonia.citd@gmail.com Tel: +918800779185
}

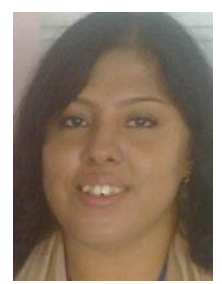

\begin{abstract}
Services were considered non-tradable in the initial stages (in the mid-eighties). However, with the advent of Information Communication and Technology (ICT) and other modern services, services have become increasingly tradable day by day. Since, the eighties, there had been a rapid expansion of the Indian service sector, surpassing the agriculture and manufacturing sector. With the expansion, important services like communication, financial, transport, insurance, research and development, business services, legal services and other professional services etc. were on high demand in the manufacturing sector. Absence of such important services would act as a bottleneck in major investment projects of a manufacturing firm. Specialized services obtained from the external agency would help the firm to focus on its non-core activities and improve its productivity growth and competitiveness. Against this backdrop, the study mainly examines the role of services in enhancing the productivity growth of the Indian Manufacturing firms since 2000. The firm level data was collected from Prowess database. The study was done at the aggregate and disaggregated level. The results conclude that services have been playing a positive role in enhancing the productivity growth of the manufacturing sector and also for the industry group like textile group, machinery group etc. However, for the Electronics Group services did not play a significant role so far.
\end{abstract}

Keywords: Services, Total factor productivity, Indian manufacturing firms.

JEL Classification: D24, L80, L60

Citation | Sonia Mukherjee (2017). The Role of Services in Total Productivity Growth of Indian Manufacturing Firms: A Firm Level Analysis Since 2000. Asian Journal of Economics and Empirical Research, 4(2): 121-131.

History:

Received: 12 September 2017

Revised: 20 November 2017

Accepted: 27 November 2017

Accepted: 27 November 2017

Licensed: This work is licensed under a Creative Commons

Licensed: This work is
Attribution 3.0 License (oc) E

Publisher:Asian Online Journal Publishing Group
Funding: This study received no specific financial support.

Competing Interests: The author declares that there are no conflicts of interests regarding the publication of this paper.

Transparency: The author confirms that the manuscript is an honest, accurate, and transparent account of the study was reported; that no vital features of the study have been omitted; and that any discrepancies from the study as planned have been explained.

Ethical: This study follows all ethical practices during writing.

\section{Contents}

1. Introduction

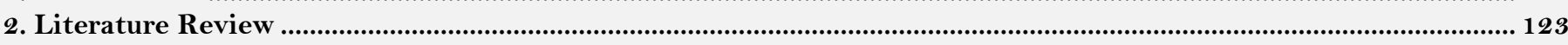

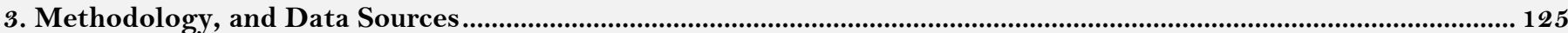

4. Description of Explanatory Variables ................................................................................................................................ 126

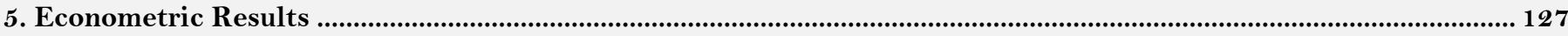

6. Regression Results for some Individual Group of Manufacturing Firms ....................................................................... 128

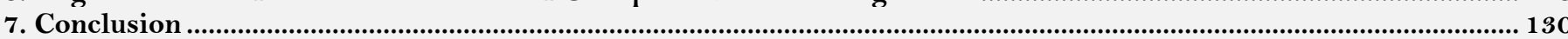

References . 


\section{Introduction}

The term "Economic growth" has generally been associated with an increase in the share of services in the Gross Domestic Product, investment and employment (Fisher, 1935; Clarke, 1940; Kuznet, 1957; Chenery, 1960; Fuch, 1968). The rising share of services along with economic growth was first noted by Clark in the1940s. Clark attributed this rise of the services to demand side factors. Different types of explanations had been provided by Fisher (1935); Kuznet (1957) to the phenomenon of increase in services associated with the economic growth. A variety of explanations and reasons have been forwarded to explain this structural change of rise in services. The main reasons forwarded and provided include high-income elasticity of demand for final product services ${ }^{1}$, slower productivity growth in services which makes contracting services from external sources more efficient and cheaper than producing them within the firm.

Most of the developing economies have undergone a significant structural shift in the last few decades. The shift was depicted through a significant decline in the share of agriculture in the total value-added and Gross Domestic Product (GDP) and a rapid increase in the share of the manufacturing followed by the service sector. Normally, this is the trend, where the primary sector witnesses a decline to be picked up by the manufacturing followed by service sector in the long run. China, for instance, had witnessed the phenomenon of agricultural sector declining followed by rise in the manufacturing sector followed by the service sector. Compared to this trend, India's structural transformation was a bit different. Followed by a decline in the primary sector (agriculture), the share of manufacturing did not increase in the value-added or GDP. It remained more or less constant at 15 percent and the service sector surpassed both the sectors and became the main contributor in value-added and GDP share. Presently, share of the service share stands to be around fifty five to sixty in total GDP share.

Cross country analyses have confirmed the fact that as the share of services increases in the aggregate output, it leads to an increase in the per capita income, and the intensity of use of services in the manufacturing sector goes up (Francois and Reinert, 1996). This has become true in the context of the Indian Economy. The Indian manufacturing firms are now readily purchasing services from external specialized bodies or agencies. This is due to the fact that the competitiveness of the manufacturing firms depend on the low cost availability of efficient producer services (Francois and Hoekman, 2010).

According to Bhagwati (1984) a part of the rise in the use of services by the manufacturing firms is due to splintering i.e. outsourcing of indirect production activities and the remaining demand for higher usage of services are attributable to structural changes in the manufacturing industries (Francois and Reinert, 1996).

In the earlier period, i.e. seventies and eighties, the Indian manufacturing firms produced a variety of services in their in-house set-up. A separate department for each types of services were operational and no outsourcing of services were done. Separate sections or department existed within the firm. Separate departments such as insurance, repair and maintenance, legal services, audit, expenses, consultancy, and others were operational. The manufacturing firm had to incur a fixed cost on all these departments. However, these costs which were found to be higher when compared to the cost charged by external service providers. A higher marginal cost of in-house production of services compelled the manufacturing firms to seek assistance of service providers who were not only specialized but also cheaper. With the increase in the share of services in the GDP share, the phenomenon of outsourcing, sub-contracting and purchasing of services from specialized service providers increased manifold. The expansion of the services provided a greater opportunity to the Indian manufacturing firms to purchase a wider range of services, instead of producing them in-house. Some notable services outsourced are business services, marketing, selling and distribution, legal, audit, insurance, financial, communication, transport and others professional services.

The various types of services has the competence to improve the firm's performance through productivity growth. For example, through intensive usage of business services, especially Information-Technology enabled services (ITes), a firm can have an up-to date knowledge about the market and knowledge about their clients. Business Process Outsourcing are a part of the ITes. Similarly, with better telecommunication services, a manufacturing firm can communicate and better coordinate with their clients and suppliers. This will further enable the firm to loose valuable time and staff in the process. Auditors are kept to examine and investigate the important documents, records, for financial or other purposes. Consultants are hired by the manufacturing firms to consult on different important matters of the firm. Marketing and advertising are important to increase the sales and performance in the market. Lastly, banking and financial service, are a vital form of service without which the firm may fail to exploit its productivity-enhancing investment opportunities. Financial constraints severely act as bottlenecks for future projects. All these services are expected to enhance the operational efficiency of the firm in terms of productivity growth. Through use of these diversified services, it will also add to the total value of the firms' produce and help in cutting down the operating costs. Following, a firm may focus on its core competencies and improve its productivity significantly.

The outsourcing of services through a specialized and efficient provider will help the firm to save costs in the long run. And further, the usage of higher quality services can help the firm to increase its competitiveness and efficiency in times of stiffer competition and globalization. Competitiveness of the manufacturing firms also depends on the availability of low cost high efficiency producer services (Francois and Hoekman, 2010). Hence, the manufacturing firms are contracting out more services which are efficient rather than producing then within the inhouse (Pilat and Wölfl, 2005). Therefore these changes taking place is resulting in an increase in the demand for services as intermediate goods ${ }^{2}$.

\footnotetext{
${ }^{1}$ There is an overlap between the output of the service industries and final product services but the former term mainly implies and includes purchase of services for intermediate activities by the firms such as repair, and maintenance, other business services etc.

${ }^{2}$ Two different methods have been chosen to explain the inter-relationship between the service sector and the manufacturing sector. One set of studies argue that the demand for the producer services grow with development and this expansion is linked to growth in round-about production and the associated conversion of the local markets into national markets (e.g. Francois (1990); Greenfield (1966); Kataozian (1970). As against this, Bhagwati (1984) Emphasized 'splintering' or 'outsourcing' of indirect production activities as a possible source for apparent growth in producer services. He put forward different ways in which technical and structural change define a continuous process during which services splinter-off goods and goods splinter-off services. He argued that which technical and structural change define a continuous process during which services splinter-off goods and goods splinter-off services. He argued that
services that splinter-off from goods are technically progressive and possibly capital intensive since these services arise due to specialization, which reflects economies of scale. But the services that are left after the goods-from services splintering process are mostly technically unprogressive and labor intensive.
} 
Services are widely used by people day to day in all spheres of their day-to- day life. Services are have also become increasingly tradable due to greater mobility of labor and technological advancement over time. This has increased the scope of specialization in production and trade. The competitiveness and productivity of the manufacturing firms (both domestic companies and exporters) crucially depends on the availability, cost and quality of crucial services like producer services such as finance, transport and telecommunications. Lack of the essential producer services reflected in the transport bottlenecks, availability of low quality telecommunication services and absence of efficient financial services can impede the proper functioning of the firms.

Hence, against this backdrop, the paper intends to study the role of services in enhancing the performance of the manufacturing firms in terms of productivity. Presently, the manufacturing firms have started taking advantage of the best outside vendors available in market and focus on the core business. This has helped the firm to build its core competencies and serve customer according to their needs. All these factors motivates us to study the role of services for growth of manufacturing firm.

\section{Literature Review}

A number of studies had been done on the use of services, its role and how they assist in improving the performance of the firm. Some studies are theoretical in nature and some are empirical in nature. This section summarizes some of the prominent studies done on services.

\subsection{Country Level Studies}

Services are heterogeneous and span over a wide range of economic activities. Conceptually, this diversity marks a fundamental function that many services perform in relation to the overall economic growth: they are inputs into the production process. One dimension of this "input function" is that service facilitates transaction through space (transport, telecommunications) or time (financial services) (Melvin, 1989).

There are a number of theoretical papers providing good number of arguments that liberalization of the barriers against foreign providers of services tends to increase the productivity of the manufacturing sector, agricultural sector and that of the services sectors productivity too. The most important papers are papers by Markusen (1989); Francois (1990a;1990b); Markusen and Venables (1998) and Markusen et al. (2005). The key ideas behind all these papers are that the providers of services increase the productivity of the users of services in manufacturing, agriculture and in the service sectors themselves. The term generally used by the economists known as "Total Factor Productivity".

Multinational providers of services are especially important in increasing the total factor productivity because they bring technology or expertise to the local production process. Theory suggests that new domestic firms will typically increase their total factor productivity. This will be done via access to a diverse set of service suppliers allowing the firms to use the services that most closely match as per their requirements. But the liberalization of the barriers against the foreign suppliers of services are required to be done as foreign services suppliers are a crucial source of new services, and the services which they are likely to offer are more likely to be different from the domestic service providers, thereby adding more to the productivity of those users whose production processes fit more naturally to the specialized services of foreign services suppliers. Markusen (1989) developed a model of trade in differentiated intermediate inputs along the lines proposed by Ethier. The model consisted of two countries having a competitive sector $(\mathrm{Y})$ and a sector $(\mathrm{X})$ which produce a composite good from intermediate inputs or services (S). The composite good was produced with the help of increasing returns to scale and were complementary in nature. The results concluded that allowing trade in specialized inputs was superior to allowing trade in final goods. Free trade in inputs/ services were found to be Pareto superior to free trade in goods from the world point of view.

Markusen et al. (2005) concluded that foreign producer services such as managerial and engineering consulting can provide substantial benefits of specialized knowledge that could be costly in terms of both time and money for domestic firms to develop on their own. The study was built on a monopolistic competition models of intermediate producer services to assess the importance of liberalization of restraints on foreign providers of producer services. Some three key assumptions were made. First, a larger variety of producer services lower the adjusted costs of these services for downstream industries; Second, producer services were produced under conditions of increasing returns to scale (Faini, 1984) and third, key inputs to producer services (e.g. foreign personnel) were affected by very different barriers than trade in goods. The Results concluded that real wage of domestic skilled labor increased the liberalization of policies against the Foreign Service providers. Also, the presence of foreign firms in the domestic market increased the real wage of domestic skilled workers. The additional foreign firms present lowered the cost of the intermediate service product in final goods production and increased the relative importance of the final good sector which used the services intensively. Results also indicated that foreign services were partial equilibrium substitutes for domestic skilled labor and service trade could provide crucial inputs which might reverse the comparative advantage in final goods.

Francois (1990a) in his study noted that the growth of the intermediation services was an important determinant of overall economic growth because they allowed specialization to occur. The reason was as firms increased their size and specialized more labor, more activity was needed to be devoted. The activity was mainly in the form of coordination and organizing core business activities and companies. The additional activity was partly outsourced to an external service providers. The producer services that were demanded and supplied played an important distinct role in coordinating the production processes. Further, they were needed to generate more differentiated goods and realize the scale economies. The associated organizational innovations and expansion of logistics (network) services yield productivity gains that in turn affected economy wide growth performance. Lastly, the greater the variety and quality of services, the larger the reduction in (real) price associated with greater specialization in services (outsourcing), the greater the impact on productivity(welfare) of firms(households) that buy services.

At the aggregate level, Eschenbach and Hoekman (2006) examined the impact of service sector policy reforms on the growth performance of the 24 transition economies from the year 1990 till 2004. Ordinary least squares 
(OLS) method with country specific fixed effects regression and controlling for a number of standard explanatory variables was used as a methodology. The results concluded that the measures of service sector reform was statistically significant in explaining the growth of the sample of twenty four countries.

King and Levine (1993a) postulated that the financial services have the potential to affect the growth through enhanced capital accumulation and technical innovation. The study controlled for factors affecting the long run growth and constructed an additional measures of financial sector development such as the ratio of liabilities of the financial system to GDP and the ratio of gross claims on the private sector to GDP. The additional measures used in the regression analysis concluded that they were statistically significant. Lastly, financial sector development in the sixties were found to be a significant predictor of the economic growth.

Mattoo et al. (2006) in their study had three objectives in mind. The first objective was to explain the impact of liberalization of the services sector and how that differed from the liberalization in the goods sector. The second objective was to measure the openness ${ }^{3}$ for the country's services regime. The third objective was to test whether the openness of the policy regime in services had an impact on the long run economic growth of the country or not. A simple regression method was applied for a sample consisting of sixty countries from 1990 till 1999. After controlling for other determinants of growth, the study found that the countries more open to telecom and financial services sectors grew up to 1.5 percentage points faster than the countries with closed regimes.

\subsection{Firm-Level Studies}

After studying the role of services at the country level, a few firm level studies dealing with the role of services in enhancing the manufacturing firm's performance are examined below.

Employing a rich panel of firm data set, Arnold et al. (2011) analyzed the far reaching reforms of service industries based on firm-level data for the period 1998 to 2003. The main objective was to establish a positive link between the extent of policy reform in service industries and productivity of the manufacturing sectors using necessary service inputs. A rich set of firm-level data was collected from Amadeus, a commercial database for the Czech companies. Subsequently, the total factor productivity (TFP) was estimated for all the manufacturing firms using an Ordinary Least Squares and semi-parametric estimation by Ollay and Pakes (1996). A national inputoutput matrix was used to obtain the reliance of manufacturing sectors on the service inputs. The results demonstrated a positive correlation between liberalization in service sectors and the productivity of manufacturing firm's relying on foreign providers in services. Results also confirmed a positive and statistically significant association between the overall index of policy reforms and downstream productivity.

Arnold et al. (2008) studied the relationship between the availability of services and the productivity of the African manufacturing firms in details. The World Bank Enterprise Surveys was used as a main data source. It contained unique measures of the performance of communications, electricity and financial services. The study exploited the variation in the service performance at the sub-regional level and the results concluded a positive association between the performance of the manufacturing firms and the indicators of the availability of services in the region.

Shepotylo and Vakhitov (2012) examined the impact of service liberalization on productivity for Ukrainian firms. The study used a data set of over 40 thousand firms in Ukraine from 2001 to 2007. A firm specific index was constructed to see the amount of service intensity and usage by the manufacturing firms. The study extended their methodology by applying a newly developed methodology of De Loeker (2011). The study concluded that a one standard deviation increase in the service sector liberalization led to a nine percent increase in the total factor productivity.

Siegel and Griliches (1992) examined the relationship between the manufacturing productivity growth and outsourcing of services from the year 1979 till 1986. The outsourcing of the services was measured in terms of average ratio of the purchased services within the manufacturing to the manufacturing output between the timeperiod 1977 till 1982. The results revealed a weak correlation between the latter measure and manufacturing productivity growth.

Raa and Wolff (2001) examined the recovery of the standard total factor productivity growth in manufacturing during the period 1977-87. The main speculation of their study was the fact, that whether the recovery of the manufacturing productivity growth was mainly due to the outsourcing of services or not. A consolidated framework initiated by the Leontief (1967) was employed. The data sources used for this study was mainly collected from the US-85 order input-output tables for 1947, 1958, 1967, 1987, 1996 in the dual use table format. The results concluded that outsourcing of services were partly responsible for the recovery of the conventional Total factor Productivity growth in manufacturing growth during the 1980 s.

\subsection{Indian Firm Level Studies}

Not many studies in the Indian context have verified the interrelationship between the role of services and manufacturing productivity growth. However, a few notable studies do exist. They are as follows:

Banga and Goldar (2004) examined the role of services to the output growth and productivity in the Indian manufacturing industries using the KLEMS production function framework. Two main data sets were used. One dataset was used at an aggregated level, i.e. for 41 major industry groups (comprising the organized manufacturing sector) for the time-period starting from 1980-81 to 1990-00 and the other data set at a more disaggregated level covering the 148 three digit industries for the period 1980-81 to 1997-98. The study constructed a multifactor total factor productivity index for the forty one major industry groups for the period 1980-81 to 1999-2000, with and without incorporating services. Thereafter, the total factor productivity index was regressed on a set of explanatory variables such as export intensity, import intensity and others including the services variable. The coefficient of the services variable turned to be positive and statistically significant at the one percent level. Following this, the TFP equation was again re-estimated after dropping some of the explanatory variables. In all 
the cases, the services variable was found to be significant at one percent level. Further, the findings also suggested the growing usage of the services contributing to a better performance in the nineties as compared to the eighties.

Arnold et al. (2010) examined India's policy reforms in services. The liberalization measures used in their study were segregated into several indexes like banking, telecommunications, transport, and insurance services. All these indexes were used for focusing on the policy reforms in the services sectors. Arnold addressed three main questions. First, had the service reforms in the present times contributed more towards the manufacturing productivity? Second, whether some manufacturers benefitted more as compared to the other firms in terms of intensive usage of services? And lastly, did the reform in the services had a bigger impact in comparison to the other reforms? The manufacturing sector's reliance on inputs from each service sector was based on the national input-output table. The results concluded that the service reforms had made a significant impact on the manufacturing firm's total productivity. The aggregate effect of the service liberalization was an increase in productivity of 11.7 percent for the domestic firms and 13.2 percent for the foreign firms for a one-standard deviation increase in the liberalization index.

Hansda (2001) found a strong relationship between the services sector and the manufacturing sector in India. The study mainly addressed two issues. Firstly, the sustainability of the services and secondly, the services-led growth of the Indian Economy. These two issues was addressed in terms of their inter-sectoral linkages as emanating from the input-output tables (1993-94) for both the disaggregated level consisting of 115 activities and aggregated level containing 10 constructed national accounts categories. The findings concluded that at the disaggregated level, the Indian economy was found to be predominantly services-intensive with fifty five percent activities directly service -intensive.

\section{Methodology, and Data Sources}

\subsection{Levinsohn and Petrin (2003) (LP) Methodology}

Before describing the methodology, we start by describing the variables which have been used in the Levinsohn Petrin Methodology.

Value-added: The Total value added of the firms has been calculated by taking the total sales of firms minus the value of materials minus the value of total services minus the value of energy inputs. Thereafter, it is deflated using a suitable wholesale price index ${ }^{4}$ for every individual manufacturing group of firms and real value-added is obtained for all the manufacturing firms.

Labor: CMIE Prowess, “Annual Financial Statement” did not have sufficient data for total laborers/employees. The database containing the number of employees were extremely thin and missing. Hence, to construct the variable "total labor", data on total emoluments and number of person days were obtained from the Annual survey of Industries (ASI) and the total wage rate was obtained. Henceforth, we took the data on "Total wages and salaries" from CMIE, prowess and divided it by the wage rate (calculated from ASI) to get the total number of employees or laborers.

Capital: Total gross fixed capital asset is collected from CMIE prowess was taken to construct the capital variable. For this purpose, the total gross fixed capital asset was divided with an "implicit deflator", i.e. the gross fixed capital stock, obtained from the National Accounts Statistics, Central Statistical Organization, and the variable "Total Capital" in real terms was obtained.

In the above equation, all the components of the value-added are expressed in real terms is the dependent variables.

Both Capital and Labor inputs (expressed in real terms) are included as independent variables. After the variable creation, the Total Factor productivity (TFP) needed in the study was estimated using the LP methodology. A number of steps was done.

To control for the unobserved and unexpected productivity shocks, a proxy was required to be taken. Henceforth, energy variable was used as a proxy to capture the unexpected productivity shocks. The value of the energy was obtained from the CMIE prowess, "Annual Financial Statements" in terms of "power, fuel and water expenses”. But energy was given in current prices. Hence, it was converted in real terms as the other variables, using a suitable energy deflator. Therefore, a price index or deflator of energy was constructed using Annual Survey of Industries (ASI) Data. For this purpose, data on the relative expenditures of the manufacturing firms on coal, petroleum products, and electricity were collected and compiled. A weighted average was created for the three indexes, coal, petroleum, and electricity. Thereafter a price index for coal, petroleum products and electricity was calculated from the WPI series. Following this, the price index of each of them is divided by the relative weighted average of each of the three indices, coal, petroleum and electricity. The relative price index obtained for the three indexes separately is added and a composite price index is formed for energy. In the last step, the energy variable obtained from CMIE was divided with relative price index and energy in real terms is obtained. And thereafter in the estimation process, the energy (in real terms) is used as a proxy to control for the productivity shocks similarly as done by the earlier works by Banga and Goldar (2004) and Mary et al. (2002).

In recent years, a greater amount of attention has been paid on the measurement of total factor productivity. The estimation of the production function by using of Ordinary least squares (OLS) does not always give consistent results and tends to give biased estimate of the explanatory variables taken for the study. Also, there are a number of effects such as firms, industries, time, and other effects which are not always observable. These unobservable effects are known to the firm but not to the researcher or academician. And these unobservable might influence the usage of inputs used in the production process and fail to address the endogeneity issue. The results obtained would therefore be inconsistent and unbiased.

To solve these issues, semi-parametric methods such as Levinsohn and Petrin (2003) had been used in a good number of studies. In our first hypothesis, we will be using the LP methodology to estimate the firm level

${ }^{4}$ The Wholesale Price Index has been obtained from the Office of the Economic Advisor, Government of India, Ministry of Commerce and Industry, DIPP. The WPI had a different base year prior to 2004-05. Hence, we had shifted the WPI to a common base year for obtaining a suitable price-index for each firm. 
production function. The LP method uses energy as the proxy for controlling unobservable productivity shocks. The detailed estimation is as follows:

We assume a production function of the form:

$$
\mathrm{Y}_{\mathrm{t}}=\beta_{o}+\beta_{k} k_{t}+\beta_{l} l_{t}+\beta_{e} e_{t}+\omega_{t}+\mu_{t} \ldots
$$

Where, $y_{t}, k_{t}, l_{t}$, and $e_{t}$ are log of output, capital stock, labor input and energy of the manufacturing firm respectively.

We represents the productivity of the firm and $\mu_{\mathrm{t}}$ stands for the measurement error in output, which is totally uncorrelated with the input choices.

To control for the unobservable productivity shock, we take energy as the proxy to take care of the endogeneity problem. LP assumes that firm's energy demand function as $e_{t}=e_{t}\left(w_{t}, k_{t}\right)$ is monotonically increasing in productivity given its capital stock. This allows inversion of energy demand function as $w_{t}=w_{t}\left(e_{t}, k_{t}\right)$. Thus the unobservable productivity term $\left(\mathrm{w}_{\mathrm{t}}\right)$ depends solely on two observed inputs, $\mathrm{e}_{\mathrm{t}}$ and $\mathrm{k}_{\mathrm{t}}$.

Rewriting Equation (2) gives us,

$$
\boldsymbol{Y}_{t}=\boldsymbol{\beta}_{1} I_{t}+\boldsymbol{\beta}_{m} \boldsymbol{m}_{t}+\psi\left(\boldsymbol{k}_{t}, \boldsymbol{e}_{t}\right)+\boldsymbol{\mu}_{t}
$$

The estimation of the production function is carried out in two stages. The first stage involves the estimation of the above equation where conditional moments $E\left(y_{t} / k_{t} e_{t}\right), E\left(l / k_{t} e_{t}\right)$ are estimated.

First moment condition identifies $\beta_{\mathrm{k}}$ by assuming that capital stock does not respond to the innovation in productivity, i.e. $E\left(\mu_{t}+\xi_{t} / k_{t}\right)=O$; second moment condition identifies b by using the fact that last period's energy choice should be uncorrelated with innovation in productivity this period,

The final estimation requires several steps ${ }^{5}$. The value of the static is computed for each of these samples and the distribution of estimates so generated provides bootstrap approximation to the sampling distribution of the statistics.

Using the estimated coefficients of production function, we estimate

$$
\text { Ln TFP } P_{j i t}=\ln y_{j i t}-\dot{v}_{l} l n l_{j j t}-\dot{v}_{k} \ln k_{j i t}-\dot{v}_{e} e_{j i t}
$$

After obtaining the TFP, we examine the role of services as an independent variable on the total factor productivity (TFP) for aggregate manufacturing firms and also for sub-groups of industries like Textiles, Food, Beverages, \& Tobacco etc separately.

The regression equation to be estimated is using the random effect ${ }^{6}$, fixed effect ${ }^{7}$ and industry effect.

The random model for the study is given below:

$$
Y_{\mathrm{ijt}}=\beta \mathrm{X}_{\mathrm{ijt}}+\alpha_{\mathrm{i}}+\mu_{\mathrm{ijt}}+\xi_{\mathrm{ijt}}
$$

Where, $\mathrm{Y}_{\mathrm{ijt}}$ is the dependent variable where, $\mathrm{i}$ is the firm, $\mathrm{j}$ is the industry and $\mathrm{t}$ is the time.

$\alpha$ is the unknown intercept of a firm.

$\mathrm{X}_{\mathrm{ijt}}$ represents the independent variables such as services, import intensity, size, exports, and age etc.

$\beta$ is the coefficients for the explanatory variables.

$\mu_{\mathrm{ijt}, \mathrm{is}}$ the error term in the equation.

$\xi_{\mathrm{ijt}}$ is the omitted term.

The rationale behind the random effects, is that, the variation across entities is assumed to be random and uncorrelated with the predictor or independent variables included in the model. It is generally believed that the difference across the firms have an influence on the dependent variable. Hence, the logic for using random effects model.

The fixed effect equation for the study is given below

$$
Y_{i j t}=\beta_{1} X_{i j t}+\alpha_{i}+\mu_{i j t}
$$

Where, $\mathrm{Y}_{\mathrm{ijt}}$ is the dependent variable where, $\mathrm{i}$ is the firm, $\mathrm{j}$ is the industry and $\mathrm{t}$ is the time.

$\alpha_{\mathrm{i}}(\mathrm{i}=1, \ldots . ., \mathrm{n})$ is the unknown intercept for each firm (firm specific intercepts).

$\mathrm{X}_{\mathrm{ijt}}$ represents the independent variables such as services, import intensity, size, exports, and age etc.

$\beta_{1}$ is the coefficients for the explanatory variables.

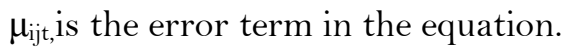

Where, $\mathrm{Y}_{\mathrm{ijt}}$ is the TFP. The Total Factor productivity tends to vary across the Indian manufacturing firms over the time.

The term $\mathrm{X}_{\mathrm{ijt}}$ represents the independent variables such as services (S), import intensity (IM), size (SI), exports $(\mathrm{Ex})$, and ownership dummy (OW) etc.

$\mathrm{S}$ denotes the real value of services used by the manufacturing firms. For the purpose of normalization, $\mathrm{S}$ is being divided by $Q$ (total output of firms). If the use of services as an input is favorable and have a positive contribution towards the manufacturing firms' performance in terms of total factor productivity than it should have a positive coefficient of $\mathrm{S} / \mathrm{Q}$.

\section{Description of Explanatory Variables}

The description of four explanatory variables used in the study are as follows.

$\mathbf{S}$ denotes the real value of services used by the manufacturing firms. For the purpose of normalization, $\mathrm{S}$ is being divided by $Q$ (total output of firms). If the use of services as an input is favorable and have a positive contribution towards the manufacturing firms' performance in terms of total factor productivity than it should have a positive coefficient of $\mathrm{S} / \mathrm{Q}$.

\footnotetext{
${ }^{5}$ Refer to Levinsohn and Petrin (2003) for detailed discussion.

${ }^{6}$ Random effects (RE) assumes that the Firm's error term is not correlated with the predictor and allows for time-invariant variables to play a role as explanatory variables. In RE, specification of the individual characteristics is required.

explanatory variables. In RE, specification of the individual characteristics is required.
7 The fixed Effect (FE) model controls for all time-invariant differences between the individuals. The estimated coefficient of the FE model cannot be biased because of the time-invariant characteristics.
} 
Export dummy: The export dummy is used to examine whether the firms who have an export propensity of more $5 \%$ are the ones who have contributed positively towards total productivity growth of manufacturing firms or not.

IM denotes the imported raw materials, stores and parts divided by total raw materials. It is expected that the use of raw materials contribute positively towards the total factor productivity of the manufacturing firms.

SI denotes the size of the firms. The size was computed by taking logarithm of sales. It is expected firms with a bigger size will contribute positively to the total factor productivity.

Lastly, $\mathbf{O W}_{1}$ denotes the ownership dummy. The ownership dummies used in the study are mainly of two types. The first ownership dummy $\mathrm{OW}_{1}$ is taken to see whether the group or the non-group firms are contributing more towards the total factor productivity growth. For group firms, the dummy is taken to be 1 and for non-group firms, the value is taken to be zero. A similar regression analysis is also performed upon a private group of firms. The second ownership dummy variable taken to be $\mathrm{OW}_{2}$. This dummy is taken to see whether the private (Indian) or the Private (foreign firms) are contributing more towards the TFP growth of the Indian manufacturing firms. For private (foreign) firms, the dummy value is taken to be 1 and for private (Indian) firms the dummy value is taken to be zero.

The above Equations (4) and (5) are estimated through both the random effect model and fixed effects models. This is done for both the aggregate group of manufacturing firms and disaggregated group of manufacturing firms. Apart from the above two models, another regression analysis was done by using the industry fixed effects.

\section{Econometric Results}

\subsection{Regression Results for the Contribution of Services towards the Productivity Growth of the Aggregate Manufacturing Firms Since 2000}

Table 1 clearly shows that the service coefficient have positively contributed to the TFP growth in case of the aggregate manufacturing firms. The other factors which have also positively contributed to the productivity growth are export dummy variable, import intensity, size, experience and ownership dummy variable. The export (E/Q) variable is also found to be positive and significant in improving the TFP growth of the aggregate manufacturing firms. The exporting firms taken here for the analysis were those whose were exporting at a rate more than 5 percent. They were found to be more productive and efficient as compared to the non-exporting firms. The size (SI) variable defined as logarithm of sales was also found to be positive and significant. The logic behind this is that the larger and medium size firms contribute more to the productivity as compared to the small-sized firms. Larger and medium firms have more access to advanced technology, skills and expertise. Hence, all these factors combined contributes to the positive impact of size on the TFP of the manufacturing firms. The import intensity variable (IM) was found to have a positive impact on the TFP at the aggregate level. The rationale here is that, as the Indian Manufacturing firms imports the essential raw materials in the form of tools, machinery and other essential equipment's, it contributes to the value-addition of the firm. Hence, the productivity of the firm rises as a result of higher value-addition. The Experience (Exp) variable also contributed positively to the TFP growth of the aggregate manufacturing firms. It is usually seen that the higher the experience, the more it becomes positively associated with the TFP of the firms. In other words, the more experience a firm acquires, the more it will contribute towards its productivity growth in the coming years.

Lastly, ownership dummy $\left(\mathrm{OW}_{1}\right)$ variable is also found to have a positive impact on the TFP of the Indian manufacturing firms. The group firms like Tata, Mahindra \& Mahindra and other group firms performed better as compared to the non-group firms in terms of productivity. The results are summarized in the Table 1.

Table-1. Role of Services in improving the TFP of the aggregate Indian manufacturing firms (Taking Ownership Dummy, OW )

\begin{tabular}{|c|c|c|c|c|}
\hline & $\begin{array}{l}\text { Panel Fixed } \\
\text { Effect }\end{array}$ & $\begin{array}{l}\text { Panel random } \\
\text { Effect }\end{array}$ & $\begin{array}{l}\text { Panel Random Effect with } \\
\text { robust standard error }\end{array}$ & $\begin{array}{l}\text { Pooled OLS with } \\
\text { Industry Fixed Effects }\end{array}$ \\
\hline $\begin{array}{l}\text { Explanatory } \\
\text { Variables }\end{array}$ & $\begin{array}{l}\text { Coefficients } \\
\text { 't' Statistics }\end{array}$ & $\begin{array}{l}\text { Coefficients } \\
\text { 't' Statistics }\end{array}$ & $\begin{array}{l}\text { Coefficients } \\
\text { 't' Statistics }\end{array}$ & $\begin{array}{l}\text { Coefficients } \\
\text { 't' Statistics }\end{array}$ \\
\hline $\mathbf{S} / \mathbf{Q}$ & $\begin{array}{l}.25 \\
(17.36)^{*}\end{array}$ & $\begin{array}{l}.26 \\
(17.34)^{*}\end{array}$ & $\begin{array}{l}.26 \\
(2.51)^{* * *}\end{array}$ & $\begin{array}{l}.20 \\
(15.06)^{*}\end{array}$ \\
\hline EX & $\begin{array}{l}.069 \\
(7.43)^{*}\end{array}$ & $\begin{array}{l}.072 \\
(7.59)^{*}\end{array}$ & $\begin{array}{l}.07 \\
(7.09)^{*}\end{array}$ & $\begin{array}{l}.03 \\
(4.24)^{*}\end{array}$ \\
\hline IM & $\begin{array}{l}.0003 \\
(3.25)^{*}\end{array}$ & $\begin{array}{l}.0003 \\
(3.39)^{*}\end{array}$ & $\begin{array}{l}.0003 \\
(4.12)^{*}\end{array}$ & $\begin{array}{l}.0003 \\
(3.86)^{*}\end{array}$ \\
\hline SI & $\begin{array}{l}1.09 \\
(352.36)^{*}\end{array}$ & $\begin{array}{l}1.07 \\
(350.37)^{*}\end{array}$ & $\begin{array}{l}1.07 \\
(295.65)^{*}\end{array}$ & $\begin{array}{l}1.09 \\
(356.85)^{*}\end{array}$ \\
\hline EXP & $\begin{array}{l}.028 \\
(4.71)^{*}\end{array}$ & $\begin{array}{l}.029 \\
(4.81)^{*}\end{array}$ & $\begin{array}{l}.029 \\
(4.81)^{*}\end{array}$ & $\begin{array}{l}.01 \\
(3.44)^{*}\end{array}$ \\
\hline $\mathbf{O W} \mathbf{W}_{1}$ & $\begin{array}{l}.21 \\
(21.53)^{*}\end{array}$ & $\begin{array}{l}.24 \\
(24.35)^{*}\end{array}$ & $\begin{array}{l}.24 \\
(23.05)^{*}\end{array}$ & $\begin{array}{l}.13 \\
(14.53)^{*}\end{array}$ \\
\hline No. of observations & 37703 & 37703 & 37703 & 37704 \\
\hline Overall $\mathbf{R}^{2}$ & 0.80 & 0.80 & 0.80 & .85 \\
\hline
\end{tabular}

* Significant at $1 \%$ level of significance, ${ }^{*}$ S Significant at $5 \%$ level of significance. Estimates in the first three column allows for firm fixed effects. Estimate in
* Significant at $1 \%$ level of significance, ** Signific
the last column allows for industry-fixed effect.

Table 2 show a similar kind of results. Here to check for the robustness of the ownership dummy, we have taken the group of private firms, i.e. not belonging to the business group, which comprised mainly the private Indian firms and private foreign firms operating in the Indian manufacturing sector. We use the symbol $\mathrm{OW}_{2}$ to represent the private dummy variable. The private Indian dummy variable was assumed to be $O$ and the private foreign variable was assumed to be one. The results show that services have played a significant role. The other variable's playing a vital role are experience, exports, and IM etc. Lastly, the private dummy variable $\mathrm{OW}_{2}$, revealed that the private foreign firms were more productive in boosting the productivity growth as compared to 
the Indian private firms. All the variables taken for the analysis had played an important role in enhancing the TFP of the Indian manufacturing firm since the year 2000 onwards. The results are shown in Table 2.

Table-2. Contribution of services on the Total factor productivity of the Indian Manufacturing since 2000 onwards

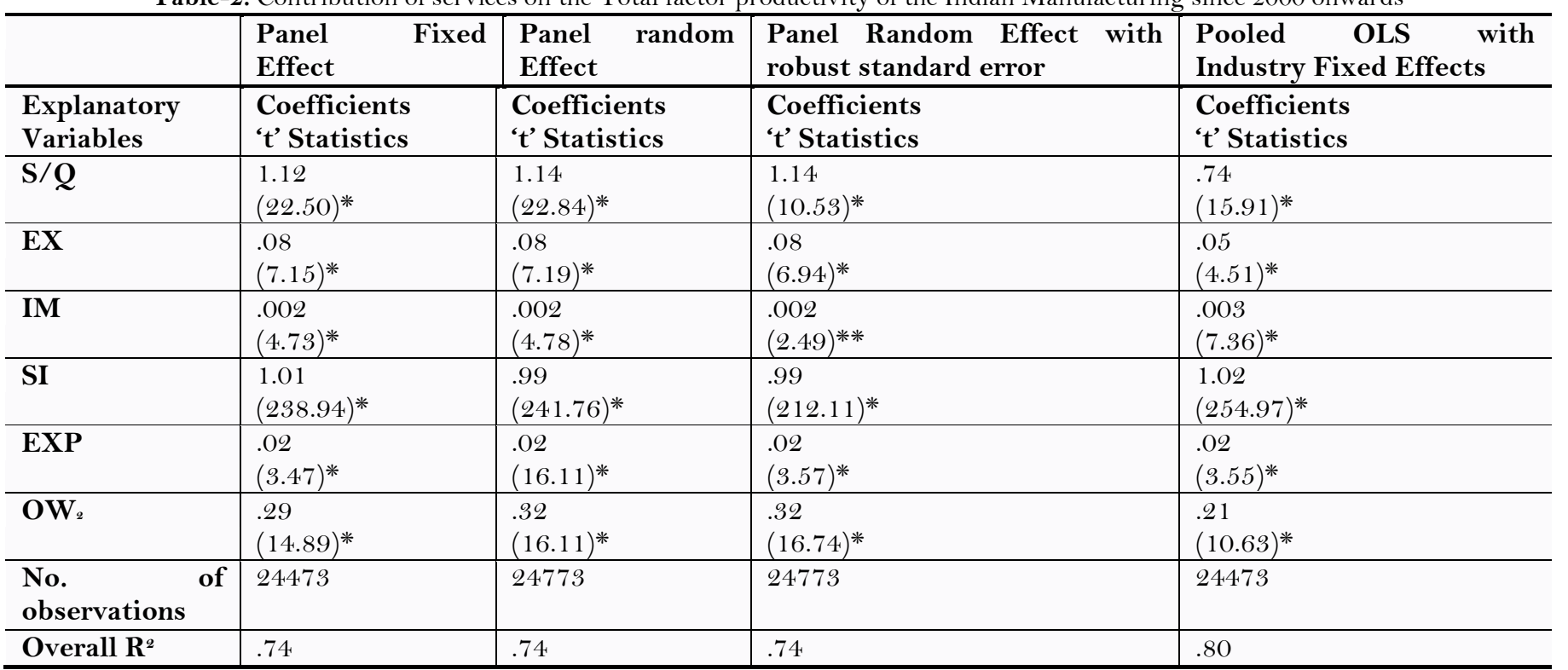

* Statistically significant at one percent, ***statistically significant at 5 percent. Estimates in the first three column allows for firm fixed effects. Estimate in the last column allows for industry-fixed effect.

\section{Regression Results for some Individual Group of Manufacturing Firms}

\subsection{Regression Results for Chemical Group of Firms}

For the analysis of the Chemical group of firms, variables such as services, IM, and Ex were found to play a positive and significant role in influencing the TFP growth of the manufacturing firms in case of random effect. The results are given in Table $3 \mathrm{a}$.

Table-3a. Contribution of services towards Total factor productivity of the Chemical group of Firms $\left(\mathrm{OW}_{1}\right)$; Dependent variable is L(TFP

\begin{tabular}{l|l|l|l}
\hline & Random Effects & Fixed Effects & Random Effects with Robust standard Error \\
\hline Explanatory variables & $\begin{array}{l}\text { Coefficients } \\
\text { 't' Statistics }\end{array}$ & $\begin{array}{l}\text { Coefficients } \\
\text { 't' statistics }\end{array}$ & $\begin{array}{l}\text { Coefficients } \\
\text { 't' Statistics }\end{array}$ \\
\hline $\mathbf{S} / \mathbf{Q}$ & .25 & .10 & .25 \\
& $(2.45)^{* *}$ & $(1.06)$ & $(1.03)$ \\
\hline $\mathbf{E X}$ & .02 & .02 & .02 \\
& $(1.02)$ & $(1.13)$ & $(0.99)$ \\
\hline $\mathbf{I M}$ & .04 & .05 & .04 \\
& $(1.02)$ & $(1.11)$ & $(0.78)$ \\
\hline SI & 1.11 & 1.14 & 1.11 \\
& $(125.65)^{*}$ & $(127.40)^{*}$ & $(110.88)^{*}$ \\
\hline EXP & .10 & .10 & .10 \\
& $(6.29)^{*}$ & $(6.33)^{*}$ & $(6.23)^{*}$ \\
\hline OW & .25 & .21 & .25 \\
& $(9.04)^{*}$ & $(7.97)^{*}$ & $(9.07)^{*}$ \\
\hline $\mathbf{N u m b e r}^{\mathbf{2}}$ & 4199 & 4199 & 4199 \\
\hline
\end{tabular}

* Statistically significant at one percent, ** statistically significant at five percent, $\mathrm{t}$ values in the parentheses

For the analysis below, we took a small number of firms, that is, private firms as compared to group firms in the earlier case. The difference with the earlier analysis is that here we have taken the private firms such as Indian and Foreign, as the ownership dummy variable. The results show that variables such as services, experience, size, exports, imports intensity and ownership dummy have contributed positively in the case of the private firms. The results are shown in Table $3 \mathrm{~b}$.

Table-3b. Contribution of services towards Total factor productivity of the Chemical firms $\left(\mathrm{OW}_{2}\right)$; Dependent variable is LTFP

\begin{tabular}{l|l|l|l}
\hline & Random Effects & Fixed Effects & Random Effects with Robust standard Error \\
\hline Explanatory variables & $\begin{array}{l}\text { Coefficients } \\
\text { 't' Statistics }\end{array}$ & $\begin{array}{l}\text { Coefficients } \\
\text { 't' statistics }\end{array}$ & $\begin{array}{l}\text { Coefficients } \\
\text { 't' Statistics }\end{array}$ \\
\hline $\mathbf{S} / \mathbf{Q}$ & $.68(5.82)^{*}$ & $.60(5.00)^{*}$ & $.68(4.84)^{*}$ \\
\hline $\mathbf{E X}$ & $.07(2.28)^{* *}$ & $.07(2.25)^{* *}$ & $.07(2.25)^{* *}$ \\
\hline $\mathbf{I M}$ & $.16(2.88)^{*}$ & $.16(2.84)^{*}$ & $.16(2.14)^{* *}$ \\
\hline $\mathbf{S I}$ & $1.09(84.82)^{*}$ & $1.02(83.10)^{*}$ & $1.00(74.29)^{*}$ \\
\hline $\mathbf{E X P}$ & $.11(5.88)^{*}$ & $.11(5.95)^{*}$ & $.11(5.86)^{*}$ \\
\hline $\mathbf{O W}$ & $.20(4.09)^{*}$ & $.15(3.16)^{*}$ & $.20(4.66)^{*}$ \\
\hline $\mathbf{N u m b e r}^{*}$ of Observations & 2608 & 2608 & 2608 \\
\hline $\mathbf{R}^{2}$ & .79 & .79 & .79 \\
\hline * Statistically significant at one percent, ** statistically significant at five percent, t values in the parentheses.
\end{tabular}




\subsection{Regression Results for the Machinery Group of Firms}

For the machinery group of firms, services have made a positive contribution in improving the productivity growth. The other variables enhancing the productivity growth are SI, IM, EX and Exp respectively. Lastly, the group firms had performed better in enhancing the productivity as compared to the non-group firms. The results are summarized in Table 4a.

Table-4a. Contribution of services towards Total factor productivity growth of the Machinery Group of Firms; Dependent Variable: Ln (Total Factor productivity)

\begin{tabular}{l|l|l|l}
\hline Explanatory variables & Random Effects & Fixed Effects & $\begin{array}{l}\text { Random Effects with Robust Standard } \\
\text { Error }\end{array}$ \\
\hline $\mathbf{S} / \mathbf{Q}$ & $\begin{array}{l}\text { Coefficients } \\
\text { 't' Statistics }\end{array}$ & $\begin{array}{l}\text { Coefficients } \\
\text { 't' statistics }\end{array}$ & $\begin{array}{l}\text { Coefficients } \\
\text { 't' Statistics }\end{array}$ \\
\hline $\mathbf{E X}$ & .13 & -.14 & .13 \\
$(-0.90)$ & $(0.28)$ \\
\hline $\mathbf{I M}$ & $(.85)$ & .15 & .14 \\
& .14 & $(4.64)^{*}$ & $(4.14)^{*}$ \\
\hline SI & $(4.46)^{*}$ & .005 & .005 \\
& .005 & $(2.67)^{*}$ & $(19.64)^{*}$ \\
\hline $\mathbf{E x p}$ & $(2.96)^{*}$ & 1.05 & 1.03 \\
& 1.03 & $(110.36)^{*}$ & $(99.97)^{*}$ \\
\hline OW & $(109.76)^{*}$ & .04 & .04 \\
& .04 & $(2.24)^{* *}$ & $(2.05)^{* *}$ \\
\hline Number of Observations & $(2.13)^{*}$ & .11 & .14 \\
$\mathbf{R}^{2}$ & .14 & $(3.41)^{*}$ & $(4.23)^{*}$ \\
\hline * Statistically significant at 1 percent, ${ }^{*} *$ statistically significant at 5 percent. & 2346 \\
\hline
\end{tabular}

In the case of private firms, with $\mathrm{OW}_{2}$ as ownership dummy, the variables such as $\mathrm{S} / \mathrm{Q}$, IM, SI and exports (EX) have made a positive contribution towards productivity growth. The results are given in Table $4 \mathrm{~b}$.

Table-4b. Contribution of services towards Total factor productivity growth of the Machinery group of Firms $\left(\mathrm{OW}_{2}\right)$; Dependent Variable: $\underline{\operatorname{Ln}(\mathrm{TFP})}$

\begin{tabular}{|c|c|c|c|}
\hline & Random Effects & Fixed Effects & Random Effects with Robust Standard Error \\
\hline Explanatory variables & $\begin{array}{l}\text { Coefficients } \\
\text { 't' Statistics }\end{array}$ & $\begin{array}{l}\text { Coefficients } \\
\text { 't' statistics }\end{array}$ & $\begin{array}{l}\text { Coefficients } \\
\text { 't' Statistics }\end{array}$ \\
\hline $\mathbf{S} / \mathbf{Q}$ & $\begin{array}{l}.73 \\
(3.88)^{*}\end{array}$ & $\begin{array}{l}.52 \\
(2.72)^{*}\end{array}$ & $\begin{array}{l}.73 \\
(2.38)^{*} * * \\
\end{array}$ \\
\hline EX & $\begin{array}{l}.17 \\
(3.99)^{*}\end{array}$ & $\begin{array}{l}.18 \\
(4.20)^{*}\end{array}$ & $\begin{array}{l}.17 \\
(3.83)^{*}\end{array}$ \\
\hline IM & $\begin{array}{l}.005 \\
(2.55)^{*}\end{array}$ & $\begin{array}{l}.004 \\
(2.30)^{* *}\end{array}$ & $\begin{array}{l}.005 \\
(17.82)^{*}\end{array}$ \\
\hline SI & $\begin{array}{l}1.01 \\
(71.47)^{*}\end{array}$ & $\begin{array}{l}1.02 \\
(71.53)^{*}\end{array}$ & $\begin{array}{l}1.01 \\
(67.70)^{*}\end{array}$ \\
\hline $\operatorname{Exp}$ & $\begin{array}{l}-0.009 \\
(-0.38) \\
\end{array}$ & $\begin{array}{l}.006 \\
(-0.26) \\
\end{array}$ & $\begin{array}{l}-.009 \\
(-0.36) \\
\end{array}$ \\
\hline $\mathbf{O W}_{2}$ & $\begin{array}{l}.08 \\
(1.84)\end{array}$ & $\begin{array}{l}.05 \\
(1.11)\end{array}$ & $\begin{array}{l}.08 \\
(1.89)\end{array}$ \\
\hline Number of Observations & 1488 & 1488 & 1488 \\
\hline $\mathbf{R}^{2}$ & .82 & .82 & .82 \\
\hline
\end{tabular}

\subsection{Regression Results for the Electronics Group of Firms}

In case of the electronics group, the services have not played an important role in improving the productivity growth. The variables enhancing productivity growth were IM, SI and $\mathrm{OW}_{1}$ respectively. The results are shown in Table 5 a below.

Table-5a. Contribution of services towards Total factor productivity growth of the Electronics group of Firms $\left(\mathrm{OW}_{1}\right)$, Dependent Variable: Ln (TFP)

\begin{tabular}{l|l|l|l}
\hline & Random Effects & Fixed Effects & Random Effects with Robust Standard Error \\
\hline Explanatory variables & $\begin{array}{l}\text { Coefficients } \\
\text { 't' Statistics }\end{array}$ & $\begin{array}{l}\text { Coefficients } \\
\text { 't' Statistics }\end{array}$ & $\begin{array}{l}\text { Coefficients } \\
\text { 't' Statistics }\end{array}$ \\
\hline $\mathbf{S} / \mathbf{Q}$ & -.04 & -.15 & -.16 \\
& $(-.24)$ & $(-0.95)$ & $(-.36)$ \\
\hline $\mathbf{E X}$ & .003 & .006 & .003 \\
& $(0.12)$ & $(0.21)$ & $(0.22)$ \\
\hline $\mathbf{I M}$ & .21 & .23 & .22 \\
& $(4.75)^{*}$ & $(5.14)^{*}$ & $(6.15)^{*}$ \\
\hline $\mathbf{S I}$ & 1.00 & 1.01 & 1.02 \\
& $(103.96)^{*}$ & $(103.39)^{*}$ & $(54.56)^{*}$ \\
\hline $\mathbf{E x p}$ & .03 & .03 & .03 \\
& $(1.55)$ & $(1.59)$ & $(1.61)$ \\
\hline $\mathbf{O W}$ & .18 & .15 & .19 \\
& $(5.75)^{*}$ & $(4.97)^{*}$ & $(5.69)^{*}$ \\
\hline Number of Observations & 3095 & 3095 & 3095 \\
\hline $\mathrm{R}^{2}$ & .81 & .81 & \\
\hline * Statistically significant at 1 percent, ** statistically significant at 5 percent & \\
& & & \\
\hline
\end{tabular}


Table-5b. Contribution of services towards Total factor productivity growth of the Electronics group of Firms $\left(\mathrm{OW}_{2}\right)$; Dependent Variable: Ln (TFP)

\begin{tabular}{l|l|l|l}
\hline \multicolumn{2}{l}{ Random Effects } & Fixed Effects & Random Effects with Robust Standard Error \\
\hline Explanatory variables & $\begin{array}{l}\text { Coefficients } \\
\text { 't' Statistics }\end{array}$ & $\begin{array}{l}\text { Coefficients } \\
\text { 't' Statistics }\end{array}$ & $\begin{array}{l}\text { Coefficients } \\
\text { 't' Statistics }\end{array}$ \\
\hline S/Q & .18 & .13 & .16 \\
$(0.97)$ & $(.68)$ & $(.78)$ \\
\hline EX & .03 & .03 & .04 \\
& $(.87)$ & $(0.92)$ & $(0.91)$ \\
\hline IM & .24 & .25 & .27 \\
& $(4.16)^{*}$ & $(4.39)^{*}$ & $(4.55)^{*}$ \\
\hline SI & .91 & .92 & .93 \\
& $(75.24)^{*}$ & $(73.18)^{*}$ & $(74.11)^{*}$ \\
\hline Exp & .05 & .04 & .05 \\
& $(2.32)^{*}$ & $(2.14)^{*}$ & $(2.01)^{*}$ \\
\hline OW 2 & .06 & .04 & .05 \\
& $(1.33)$ & $(0.89)$ & $(1.11)$ \\
\hline Number of Observations & 1976 & 1976 & 1976 \\
\hline $\mathbf{R}^{2}$ & .78 & .78 & .78 \\
\hline * Statistically significant at one percent, t values in the parentheses &
\end{tabular}

The above results indicate the private firms belonging to the Electronics group with ownership dummy $\mathrm{OW}_{2}$ have contributed positively towards the productivity growth. The other variables including services have played a positive as well as significant role in improving productivity.

\section{Conclusion}

To test and examine the proposition, that services are playing a positive role in improving the productivity growth for Indian manufacturing firms, an econometric analysis, using fixed and random effects was conducted. The results clearly showed that services are playing a positive role for improving the productivity growth of the Indian manufacturing firms since 2000. The econometric analysis was done separately at the aggregate Indian manufacturing firms as well as the disaggregated level. Overall, the results were similar with an exceptional case for the Electronics group.

An unbalanced data-set collected from prowess database was used for this purpose. But before proceeding towards the econometric analysis and estimation, the data-set was cleaned. The outliers detected were removed. There were also problems of missing values. But in spite of all these problems, around 3500 firms were found and the services variable was calculated by compiling all expenses incurred by the manufacturing firms on different heads such as professional services, business services, legal services, IT services, banking and financial services, insurance and transport services, marketing, selling and distribution etc. The expenses of the manufacturing firms towards these services gave us a brief idea how much these services were used by the different manufacturing groups.

After construction of the service variable, we regressed the services variable and the other variables such as Exp, EX, SI, IM, and OW on the TFP of the manufacturing firms. The analysis was done separately for both for aggregate and individual sub-groups.

The results were found to be positive for aggregate group of manufacturing firms. Both $\mathrm{OW}_{1}$ and $\mathrm{OW}_{2}$, had positively and significantly affected the TFP of the manufacturing firms. The other variables such as Import Intensity (IM), Size (SI), Exports (EX) and Experience (Exp) also played a prominent role in improving the TFP of the Indian manufacturing Firms. However, for Electronics group, services did not play an important role except for the ownership group, $\mathrm{OW}_{2}$.

So, from the study, we clearly see manufacturing firms have been able to successfully utilize the benefits of the expansion in the service sector. More service usage will help them in enhancing their productivity growth and achieve a higher GDP share and value-added in the near future.

\section{References}

Arnold, J.M., B. Javorick, M. Lipscomb and A. Mattoo, 2010. Service reform and manufacturing performance: Evidence from India. Centre for Economic Policy Research, CEPR, Discussion PaperNo. 8011.

Arnold, J.M., B. Javorick and A. Mattoo, 2011. Does service liberalization benefit manufacturing firms? Evidence from Czech Republic. Journal of International Economics, 85(1): 136-146. View at Google Scholar | View at Publisher

Arnold, J.M., A. Mattoo and G. Narciso, 2008. Service inputs and firm productivity in Sub-Saharan Africa: Evidence from firm level data. Journal of African Economies, 17(4): 578-599. View at Google Scholar | View at Publisher

Banga and Goldar, 2004. Contribution of services to output growth and productivity in Indian manufacturing: pre and post reforms. ICRIER Working Paper, No. 139: 1-27.

Bhagwati, J.N., 1984. Why are services cheaper in the poor countries? Economic Journal, 94(374): 279-286. View at Google Scholar |View at Publisher

Chenery, H.B., 1960. Pattern of industrial growth. American Economic Review, 50(4): 624-654. View at Google Scholar

Clarke, C., 1940. The conditions of economic progress. London: Macmillan.

De Loeker, 2011. Product differentiation, multiproduct firms and estimating the impact of trade liberalization on productivity. Econometrica, 79(5): 1407-1451. View at Google Scholar | View at Publisher

Eschenbach, F. and B. Hoekman, 2006. Service policy reform and economic growth in transition economies. Review of World Economics, 142(4): 746-764. View at Google Scholar | View at Publisher

Faini, R., 1984. Increasing returns non-traded inputs and regional development. Economic Journal, 94(374): 308-323. View at Google Scholar | View at Publisher

Fisher, A.G.B., 1935. The clash of progress and security. London: Mac Millan \& Co. Ltd.

Francois, J. and B. Hoekman, 2010. Service trade and policy. Journal of Economic Literature, 48(3): 642-692. View at Google Scholar

Francois, J.F., 1990. Producer services, scale and division of labor. Oxford Economic Papers, 42(4): 715-729. View at Google Scholar |View at Publisher

Francois, J.F., 1990a. Trade in producer services and return due to specialization under monopolistic competition. Canadian Journal of Economics, 23: 109-124.

Francois, J.F., 1990b. Producer services, scale, and the division of labor. Oxford Economic Papers, 42(4): 715-729. 
Francois, J.F. and K. Reinert, 1996. The role of services in the structure of production and trade; stylized facts from a cross-country analysis. Asia Pacific Economic Review, 2(1): 35-43. View at Google Scholar

Fuch, V., 1968. The service economy. Retrieved from https://www.oecd.org/sti/ind/2090561.pdf.

Greenfield, H.I., 1966. Man-power and the growth of the producer services.

Hansda, S., 2001. Sustainabilty of service-led growth: An input-output analysis of the Indian economy. Reserve Bank of India Occasional Working Paper Series, New Delhi, India, 22.

Kataozian, M.A., 1970. The development of the service sector: A new approach. Oxford Economic Papers, 22(3): 362-382. View at Google Scholar I View at Publisher

King, R.G. and R. Levine, 1993a. Finance and growth: Schumpeter might be right. Quarterly Journal of Economics, 108(3): 717-737.

Kuznet, S., 1957. Summary of discussion and postscript to w w Rostow, John R. Meyer and Alfred H Conrad- the Integration of Economic Theory and Economic History, 17: 545-553.

Leontief, W., 1967. An alternative to aggregation in input-output analysis and national accounts. Review of Economics and Statistics, 49(3): 412-419. View at Google Scholar View at Publisher

Levinsohn, J. and A. Petrin, 2003. Estimating production function using inputs to control for unobservables. Review of Economic Studies, 70(2): 317-341. View at Google Scholar | View at Publisher

Markusen, J., T.F. Rutherfold and D. Tarr, 2005. Foreign direct investment in services and the domestic market for expertise. 1-52. Retrieved from http://elibrary.worldbank.org/doi/pdf/10.1596/1813-9450-2413.

Markusen, J.R., 1989. Trade in producer services and in other specialized intermediate inputs and differentiated final goods. Journal of International Economics, 79(1): 85-95. View at Google Scholar Markusen, J.R. and A. Venables, 1998. Multinational firms and new trade theory. Journal of International Economics, 46(2): 183-203. View at
Google Scholar | View at Publisher

Mary, H.-D., I. Giuseppe and S.L. Kenneth, 2002. Exports and manufacturing productivity in East Asia: A comparative analysis with firm level data, NBER Working Paper No. 8894: 1-63. Retrieved from http://www.nber.org/papers/w8894.

Mattoo, A., R. Rathindran and A. Subramanian, 2006. Measuring service trade liberalization and its impact on economic growth: An illustration. Journal of Economic Integration, 21(1): 64-98. View at Publisher

Melvin, J.R., 1989. Trade in producer services: A Hecksher Ohlin approach. Journal of Political Economy, 97(5): 1180-1 196. View at Google Scholar | View at Publisher

Ollay, G.S. and A. Pakes, 1996. The dynamics of productivity in the telecommunictaions equipment industry. Econometrica, 64(6): 12631297. View at Publisher

Pilat, D. and A. Wölfl, 2005. Measuring the interaction between manufacturing and services, organisation for economic co-operation and development. OECD STI Working Papers, No. 5.

Raa, T. and Wolff, 2001. Outsourcing of services and the productivity recovery in the United States manufacturing in the $1980 \mathrm{~s}$ and the 1990s. Journal of Productivity Analysis, 16(2): 149-165. View at Google Scholar

Shepotylo, O. and V. Vakhitov, 2012. Impact of service liberalization on productivity of manufacturing firms: Evidence from Ukrainian firm level data. SSRN Working Paper.

Siegel, D. and Z. Griliches, 1992. Purchases services, outsourcing computers, and productivity in manufacturing. In Griliches. Z. (Ed), Output measurement in the service sector. IL: University of Chicago Press. pp: 429-458. 